\title{
An update on genetic basis of generalized pustular psoriasis (Review)
}

\author{
JIAHONG ZHOU, QING LUO, YANG CHENG, XIA WEN and JINBO LIU
}

Department of Laboratory Medicine, Affiliated Hospital of Southwest Medical University, Luzhou, Sichuan 646000, P.R. China

Received October 18, 2020; Accepted March 11, 2021

DOI: $10.3892 / \mathrm{ijmm} .2021 .4951$

\begin{abstract}
Generalized pustular psoriasis (GPP) is a rare and severe auto-inflammatory skin disease that is characterized by recurrent, acute onset, and generalized pustular eruptions on erythematous, inflamed skin. GPP is traditionally classified as a variant of psoriasis vulgaris, even though recent clinical, histological and genetic evidence suggests that it is a heterogeneous disease and requires a separate diagnosis. In recent years, variants of IL36RN, CARD14, APIS3 and MPO genes have been identified as causative or contributing to genetic defects in a proportion of patients affected by GPP. These disease-related genes are involved in common inflammatory pathways, in particular in the IL-1/IL-36-chemokines-neutrophil pathogenic axis. At present, no standard therapeutic guidelines have been established for GPP management, and there is a profound need for novel efficacious treatments of GPP. Among them, biological agents antagonizing the IL-36 pathway are promising therapeutics. The aim of the present review is to provide the most recent updates on the genetics, genotype-phenotype correlation and pathological basis of GPP, as well as on biologic treatments available for GPP and relative clinical courses.
\end{abstract}

\section{Contents}

1. Introduction

2. Mutation update on disease-causing gene associated with GPP

3. IL-1/IL-36-chemokine-neutrophil axis is a potent driver of disease pathology in GPP

4. Novel biologics treatment for GPP based on pathoimmunology

5. Conclusion and perspectives

Correspondence to: Professor Jinbo Liu, Department of Laboratory Medicine, Affiliated Hospital of Southwest Medical University, 25 Taiping Street, Luzhou, Sichuan 646000, P.R. China E-mail: liulab2019@163.com

Key words: generalized pustular psoriasis, mutation, IL36RN gene, $C A R D 14$ gene, $A P 1 S 3$ gene, $M P O$ gene, pathoimmunology, biologics treatment, heterogeneity

\section{Introduction}

Generalized pustular psoriasis (GPP) is a rare and severe auto-inflammatory skin disease with life-threatening potential that is characterized by recurrent and sudden episodic generalized erythematous eruptions with neutrophil-filled pustules1 $(1,2)$. GPP is accompanied by high fever, leukocytosis and elevated serum levels of C-reactive protein in the acute phase, and can be triggered by infections, pregnancy or drugs $(1,2)$. GPP is an extremely rare form of psoriasis with an estimated prevalence of 7.46 patients per million in Japan (3) and 1.76 patients per million in France (4), and represents about $1 \%$ of all clinical types of psoriasis (5-8). Histologically, GPP is characterized by Kogoj's spongiform pustule and Munro's microabscesses with a large number of infiltrating neutrophils $(9,10)$. GPP is clinically heterogeneous in presentation and progression, and currently lacks consistent classification. Concerning clinical presentation, GPP is considered one of the distinct subtypes of pustular psoriasis (PP), which can present as a recurrent systemic illness (GPP) or chronic localized form affecting palms and/or soles (palmoplantar pustulosis, PPP), or digits/nail beds (acrodermatitis continua of Hallopeau, ACH) $(1,11,12)$. Since GPP often presents in individuals with an existing history of psoriasis vulgaris (PV), it can be divided into two subtypes, namely GPP alone and GPP with PV. Patients affected by GPP alone generally carry genetic variations of $I L 36 R N$ and show more severe clinical symptoms, early acute onset of the disease, repeated and persistent attacks, and systemic inflammation $(13,14)$. According to age of onset, GPP can be classified into pediatric-onset GPP ( $\leq 18$ years) and adult-onset GPP, with pediatric-onset GPP manifesting mostly as GPP alone and occurring with recurrent and sudden systemic inflammation (15-17). GPP, especially the pediatric-onset GPP form, is considered to be an independent subtype of psoriasis which differs from PV and requires a distinct diagnosis.

Although the first GPP case was reported in 1910, its etiology and detailed pathogenesis have been only recently described in the literature. In 2011, the identification of loss-of-function mutations in IL36RN gene emphasized the key role of this pathway in the pathogenesis of GPP (18). Since then, an increasing number of genetic variants in CARD14, $A P I S 3$, and MPO pathogenic genes have been found to be associated with GPP in affected individuals (19-21). Subsequent to the identification of disease-causing genes, the pathogenesis 
of GPP has progressively been characterized and new specific biological agents have been developed.

In the present review, the aim was to assess current knowledge on the genetic basis and molecular details of the cutaneous pathomechanisms and specific treatments available on GPP and relative clinical courses.

\section{Mutation update on disease-causing gene associated with GPP}

In recent years, a number of allelic variations and mutations in IL36RN, CARD14, APIS3 genes, as well as in the latest identified pathogenic $M P O$ gene have been found to be associated with GPP (18-21). Among those genes, IL36RN mutations are the most frequent genetic abnormality $(22,23), C A R D 14$ mutations are primarily present in GPP with PV and rarely in GPP alone $(24,25)$. The pathogenic variants of APIS3 were mainly found in individuals of European origin and rarely in East Asians $(20,26)$.

\section{Disease-causing gene IL36RN}

Pathogenic mechanism underlying IL36RN mutations. Mutations in IL36RN gene are likely to be the main molecular genetic basis defect in patients affected by GPP (22). Interleukin-36 (IL-36) refers to three related IL-1 family cytokines, IL-36 $\alpha$, IL-36 $\beta$, and IL-36 $\gamma$, which can activate the downstream pro-inflammatory nuclear factor- $\mathrm{\kappa B}(\mathrm{NF}-\kappa \mathrm{B})$ and mitogen-activated protein kinase (MAPK) pathways by binding to IL-36 receptor (IL-36R). Subsequently, IL-36s induce the release of inflammatory mediators and chemotaxis that promote activation of neutrophils, macrophages, dendritic cells, and $\mathrm{T}$ cells, ultimately causing the amplification of inflammatory responses (27). IL-36 receptor antagonist (IL-36Ra) encoded by IL36RN gene is specifically expressed by epidermal keratinocytes (28) and can compete with IL-36 via binding to IL-36R, thereby blocking the inflammatory responses caused by IL-36 itself (29). The loss of function mutations in IL36RN gene results in the inability of IL-36Ra to antagonize and limit the pro-inflammatory effects of IL-36 $(18,30)$, thereby leading to increased expression of pro-inflammatory cytokine regulated by transcription factor NF- $\kappa$ B and MAPK, such as IL-8, CXCL1-3, IL-1, and even IL-36 itself, thus forming a vicious cycle of enhancing inflammation. IL-8 and CXCL1-3 are strong neutrophil chemokines and the upregulation of their expression contributes to the neutrophils infiltrating in skin pustules and systemic inflammation of GPP patients (31).

Identification of the IL36RN gene mutations in GPP patients. In 2011, Marrakchi et al (18) first reported that 9 familial Tunisian GPP patients carried the c.80T $>C$ (p.Leu27Pro) homozygous missense mutation in IL36RN, which determines increased keratinocyte expression of the inflammatory cytokines in GPP patients, such as IL-8, IL-36 $\alpha$, IL-36 $\beta$, and IL-36 $\gamma$. Therefore, IL36RN was identified as a causative gene for GPP patients and the disease caused by IL-36Ra decrease was defined as deficiency of interleukin thirty-six-receptor antagonist (DITRA) $(18,28,32)$. Notably, patients with DITRA primarily involved the skin and presented with high-grade fever and general malaise during an attack, in contrast to deficiency of interleukin-1-receptor antagonist (DIRA), an autoinflammatory disease related to activation of the IL-1 pathway, even if they suffered from similar skin manifestations $(18,32,33,34)$. Then, Onoufriadis et al (30) revealed the c.338C $>\mathrm{T}$ (p.Ser113Leu) homozygous missense substitution and the c.338C $>$ T (p.Ser113Leu) and c.142C $>$ T (p.Arg48Trp) compound heterozygote missense mutations in IL36RN gene in sporadic GPP cases in the UK. Subsequently, a set of functional relevant variants in $I L 36 R N$ gene, such as c.28C $>\mathrm{T}$ (p.Arg10X, c.104A >G (p.Lys35Arg), c.140A >G (p.Asn47Ser), c.227C $>\mathrm{T}$ (p.Pro76Leu), c.304C $>\mathrm{T}$ (p.Arg102Trp), c.305G $>\mathrm{A}$ (p.Arg102Gln), c.368C $>\mathrm{G}$ (p.Thr123Arg), c.368C $>\mathrm{T}$ (p.Thr123Met), and c.115+6T>C (p.Arg10ArgfsX1), were identified in GPP patients of Eastern Asia (15,35-37). According to sequencing and functional analysis of GPP patients from different populations, a total of 25 possible pathogenic variants in the IL36RN gene have been reported thus far (Fig. 1A and Table I). The majority of these genetic variants are missense substitutions, or to a lesser extent, nonsense mutations. The latter include c.28C $>\mathrm{T}$ (p.Arg10X), c.41C >A (p.Ser14X), c.280G >T (p. Glu94X) and c.338C >A (p.Ser113X) mutations that generate termination codons after the base substitutions. In addition, the c. $115+6 \mathrm{~T}>\mathrm{C}$ mutation in a splicing site of IL36RN causes the skipping of exon3 at mRNA level, leading to a frameshift and premature protein termination (p.Arg10ArgfsX1) (37). Furthermore, small fragment deletions (c.420_426del and c.295-300del) have been also identified in GPP patients. The c.420_426del mutation in exon 5 results in a frameshift starting from the amino acid 140, as well as in premature stop codon formation at position 170 (38). On the other hand, the c.295-300del variant leads to thr99 and phe100 amino acid deletion (23). Although the c.338C $>\mathrm{T}$ substitution is the most frequent variant in Europeans (39) c.115+6T $>C$ is the most common in Asian populations (37,40-42). In vitro functional assays have shown that $I L 36 R N$ gene pathogenic mutations lead to a decrease in the expression or activity of IL36Ra and increase of IL-36-dependent pro-inflammatory factors activated by NF- $\mathrm{BB}$ pathway (i.e., IL-1 $\beta$, IL-8, IL-36). For instance, the c.80T $>\mathrm{C}$ (p.Leu27Pro), c.28C $>\mathrm{T}$ (p.Arg10X), c.280G $>$ T (p.Glu94X), c.368C $>$ G (p.Thr123Arg), c.368C $>$ T (p.Thr123Met) and c.227C $>\mathrm{T}$ (p.Pro76Leu) homozygous missense mutations result in functional impairment of IL-36Ra protein expression and capacity to suppress downstream inflammatory responses (38). However, the function of some variants remains to be elucidated. Interestingly, homozygous or heterozygous variants in $I L 36 R N$ gene, such as c.115+6T $>C$, have also been identified in healthy cohorts (15). Findings of those studies indicate that the onset of GPP depends on a combination of multiple genetic factors, rather than a single inherited gene.

Genotype-phenotype correlation. Since some GPP cases are accompanied by PV, Sugiura et al (13) first screened the IL36RN gene in two subgroups of GPP patients in the Japanese population (GPP alone and GPP with PV, respectively), showing that all the GPP patients without PV $(n=11)$ harbored homozygous or compound heterozygous mutations in IL36RN gene $(13,48)$, whereas only 2 out of 20 cases of GPP with PV carried compound heterozygous mutations. Since the frequency of IL36RN mutations in patients of 
Table I. Mutations of IL36RN gene and related characteristics in GPP patients.

\begin{tabular}{|c|c|c|c|c|c|c|c|}
\hline $\begin{array}{l}\text { Nucleotide } \\
\text { variations }\end{array}$ & $\begin{array}{l}\text { Amino acid } \\
\text { variations }\end{array}$ & $\begin{array}{l}\text { Variant } \\
\text { type }\end{array}$ & $\begin{array}{l}\text { Status of the } \\
\text { mutations }\end{array}$ & Origin & $\begin{array}{l}\text { Protein } \\
\text { expression } \\
\text { in vitro }\end{array}$ & $\begin{array}{l}\text { Inflammation } \\
\text { inhibition } \\
\text { in vitro }\end{array}$ & (Refs.) \\
\hline c. $28 \mathrm{C}>\mathrm{T}$ & p.Arg 10X & Nonsense & Hom/CHet & $\begin{array}{l}\text { Japanese/ } \\
\text { Palestinian }\end{array}$ & None & Impaired & $\begin{array}{c}(13,35-38 \\
43,44)\end{array}$ \\
\hline c. $41 \mathrm{C}>\mathrm{A}$ & p.Ser14X & Nonsense & Hom & Algerian & None & Impaired & (38) \\
\hline c. $62 \mathrm{~T}>\mathrm{C}$ & p.Leu21Pro & Missense & Hom & Pakistani & Not reported & Not reported & (45) \\
\hline c.80T $>C$ & p.Leu27Pro & Missense & Hom & Tunisian & None & Impaired & $(18,38,46)$ \\
\hline c. $95 \mathrm{~A}>\mathrm{G}$ & p.His32Arg & Missense & Hom & Iraqi & Reduced & Impaired & $(23,38,47)$ \\
\hline c. $104 \mathrm{~A}>\mathrm{G}$ & p.Lys35Arg & Missense & Het/CHet & British & Unchanged & Unchanged & $(22,38,39)$ \\
\hline c. $125 \mathrm{~T}>\mathrm{A}$ & p.Ile42Asn & Missense & Hom & Japanese & Not reported & Not reported & (48) \\
\hline c. $130 \mathrm{G}>\mathrm{A}$ & p.Val44Met & Missense & CHet & $\begin{array}{l}\text { Chinese/ } \\
\text { German }\end{array}$ & Not reported & Not reported & $(22,23,42)$ \\
\hline c. $140 \mathrm{~A}>\mathrm{G}$ & p.Asn47Ser & Missense & $\begin{array}{l}\text { Hom/CHet/ } \\
\text { Het }\end{array}$ & Chinese & Not reported & Not reported & $\begin{array}{c}(15,16,42, \\
49)\end{array}$ \\
\hline c. $142 \mathrm{C}>\mathrm{T}$ & p.Arg 48Trp & Missense & Het/CHet & $\begin{array}{l}\text { British/ } \\
\text { German }\end{array}$ & Reduced & Reduced & $\begin{array}{c}(22,23,30, \\
38,47)\end{array}$ \\
\hline c. $169 \mathrm{G}>\mathrm{A}$ & p.Val57Ile & Missense & Het & Chinese & Not reported & Not reported & (16) \\
\hline c. $227 \mathrm{C}>\mathrm{T}$ & p.Pro76Leu & Missense & $\begin{array}{l}\text { Hom/CHet/ } \\
\text { Het }\end{array}$ & $\begin{array}{l}\text { Chinese/ } \\
\text { Turkish/ } \\
\text { German/ } \\
\text { Bosnian/ } \\
\text { Syrian/ } \\
\text { Malay }\end{array}$ & None & Impaired & $\begin{array}{c}(15,16,22, \\
23,38,42, \\
47,49)\end{array}$ \\
\hline c. $245 \mathrm{C}>\mathrm{T}$ & p.Pro82Leu & Missense & Het & Chinese & Not reported & Not reported & (16) \\
\hline c. $280 \mathrm{G}>\mathrm{T}$ & p.Glu94X & Nonsense & CHet & German & None & Impaired & $(23,39,47)$ \\
\hline c. $304 \mathrm{C}>\mathrm{T}$ & p.Arg 102Trp & Missense & $\begin{array}{l}\text { Hom/CHet/ } \\
\text { Het }\end{array}$ & $\begin{array}{l}\text { British/ } \\
\text { Turkish/ } \\
\text { East Asian }\end{array}$ & Unchanged & Unchanged & $\begin{array}{c}(22,38,39 \\
42)\end{array}$ \\
\hline c. $305 \mathrm{G}>\mathrm{A}$ & p.Arg 102Gln & Missense & Het & Chinese & Not reported & Not reported & (15) \\
\hline c. $308 \mathrm{G}>\mathrm{A}$ & p.Arg 103Gln & Missense & Het & German & Not reported & Not reported & (23) \\
\hline c. $334 \mathrm{G}>\mathrm{A}$ & p.Glu112Lys & Missense & CHet & Chinese & Not reported & Not reported & (49) \\
\hline c. $338 \mathrm{C}>\mathrm{T}$ & p.Ser113Leu & Missense & $\begin{array}{l}\text { Hom/CHet/ } \\
\text { Het }\end{array}$ & $\begin{array}{l}\text { British/ } \\
\text { German/ } \\
\text { Iraqi/ } \\
\text { Swiss/ } \\
\text { Russian }\end{array}$ & Reduced & Reduced & $\begin{array}{c}(17,22,23, \\
30,38,39, \\
47,50)\end{array}$ \\
\hline c. $338 \mathrm{C}>\mathrm{A}$ & p.Ser113X & Nonsense & CHet & Russian & Not reported & Not reported & $(23)$ \\
\hline c. $368 \mathrm{C}>\mathrm{G}$ & p.Thr123Arg & Missense & $\mathrm{CHet}$ & Japanese & None & Impaired & $(37,38)$ \\
\hline c. $368 \mathrm{C}>\mathrm{T}$ & p.Thr123Met & Missense & $\mathrm{CHet}$ & $\begin{array}{l}\text { Japanese/ } \\
\text { Chinese }\end{array}$ & None & Impaired & $(16,36,38)$ \\
\hline c. $115+6 \mathrm{~T}>\mathrm{C}$ & p.Arg 10ArgfsX1 & Frameshift & $\begin{array}{l}\text { Hom/CHet/ } \\
\text { Het }\end{array}$ & $\begin{array}{l}\text { Japanese/ } \\
\text { Chinese/ } \\
\text { Malay/ } \\
\text { Korean/ } \\
\text { German }\end{array}$ & Not reported & Not reported & $\begin{array}{c}(13,15-17, \\
22,37,39, \\
42,49, \\
51-53)\end{array}$ \\
\hline c.295-300del & p.Thr99_Phe100del & $\begin{array}{l}\text { Small } \\
\text { fragment }\end{array}$ & $\begin{array}{l}\text { CHet } \\
\text { deletion }\end{array}$ & German & Not reported & Not reported & (23) \\
\hline c.420_426del & p.Gly141MetfsX29 & Frameshift & Hom & $\begin{array}{l}\text { Spanish/ } \\
\text { Algerian }\end{array}$ & None & Impaired & $(17,38)$ \\
\hline
\end{tabular}

Hom, homozygous; Het, heterozygous; CHet, compound heterozygous. 
Table II. Studies of correlation between IL36RN mutations and clinical phenotype.

\begin{tabular}{|c|c|c|c|c|c|c|c|}
\hline \multirow[b]{2}{*}{ Studies, year } & \multirow[b]{2}{*}{ Origin } & \multirow[b]{2}{*}{$\begin{array}{l}\text { No. of patients } \\
\text { enrolled }\end{array}$} & \multicolumn{4}{|c|}{$\begin{array}{l}\text { Correlation between IL36RN mutations } \\
\text { and clinical presentations }\end{array}$} & \multirow[b]{2}{*}{ (Refs.) } \\
\hline & & & $\begin{array}{l}\text { Low prevalence } \\
\text { of PV }\end{array}$ & $\begin{array}{l}\text { Early age } \\
\text { of onset }\end{array}$ & $\begin{array}{c}\text { Severe } \\
\text { inflammation }\end{array}$ & $\begin{array}{l}\text { High recurrence } \\
\text { rate }\end{array}$ & \\
\hline Sugiura et al, 2013 & Japanese & 31 & $\mathrm{Y}$ & $\mathrm{N} / \mathrm{A}$ & N/A & $\mathrm{N} / \mathrm{A}$ & (13) \\
\hline Li et al, 2014 & Chinese & 62 & Y & $\mathrm{N} / \mathrm{A}$ & $\mathrm{N} / \mathrm{A}$ & $\mathrm{N} / \mathrm{A}$ & (16) \\
\hline Hussain et al, 2015 & $\begin{array}{l}\text { European, Asian, } \\
\text { African }\end{array}$ & 233 & $\mathrm{Y}$ & $\mathrm{Y}$ & $\mathrm{Y}$ & N/A & (17) \\
\hline Wang et al, 2017 & Chinese & 66 & $\mathrm{~N} / \mathrm{A}$ & $\mathrm{Y}$ & $\mathrm{Y}$ & $\mathrm{Y}$ & $(42)$ \\
\hline Twelves et al, 2019 & $\begin{array}{l}\text { European, } \\
\text { East Asian, Malay }\end{array}$ & 251 & $\mathrm{Y}$ & $\mathrm{Y}$ & N/A & $\mathrm{Y}$ & (22) \\
\hline
\end{tabular}

Y, yes; N/A, not applicable.

GPP alone was much higher than that observed in patients with both GPP and PV forms, Sugiura et al (13) suggested that GPP alone represents a distinct subtype of GPP and is etiologically distinguishable from GPP occurring with PV. In 2014, the genetic heterogeneity in different subtypes of GPP also was validated in a study analyzing IL36RN mutations in GPP Chinese patients (16). Consistently, the meta-analysis of 233 GPP patients by Hussain et al in 2015 (17) revealed that carriage of IL36RN mutations manifested early onset of the disease $\left(17 \pm 2.4\right.$ years vs. $33 \pm 1.5$ years; $\left.\mathrm{P}=5.9 \times 10^{-3}\right)$, higher risk of systemic inflammation ( 83 vs. $56 \% ; \mathrm{P}=1.5 \times 10^{-3}$ ), and lower prevalence of PV (36.1 vs. $68.7 \%, \mathrm{P}=5 \times 10^{-4}$ ). Of note, findings of that study also demonstrated that the number of mutant alleles of IL36RN gene also correlated with a younger age of onset. In 2017, further genotype-phenotype correlation analysis of 66 Chinese children with GPP alone also validated that IL36RN-positive cases manifested a more severe clinical phenotype, characterized by early onset, severe inflammation in skin lesions, and high recurrence rate following treatment with low-dose acitretin (42). In 2019, a survey including a cohort of 251 cases of GPP patients from multiple countries also showed IL36RN gene mutations associated with the age of onset, prevalence of PV, and recurrence rate of GPP (22). Taken together, the aforementioned studies demonstrated that IL36RN gene mutations are, not only related to the pathogenesis of GPP, but also to the clinical phenotype associated to GPP (Table II).

Disease-causing gene CARD14. CARD14 gene, also known as CARMA2 gene, encodes caspase recruitment domain family member 14 (CARD14) which mediates the activation of TRAF2-dependent NF- $\mathrm{B}$ signaling in keratinocytes $(54,55)$. CARD14 expression is mostly restricted to the basal layer of epidermis in healthy skin, whereas it is upregulated in the granular layers in GPP-affected skin (19).

In 2012, Jordan et al (19) identified the c.349G $>A$ (p.Gly117Ser) and c.349+5G >A heterozygosity in CARD14 gene in European ancestry with psoriasis, and the c.413A $>C$ (p.Glu138Ala) variant in a sporadic pediatric case with GPP. The gain-of-function mutations of c.413A $>C$ and c.349+5G $>A$ caused enhanced $\mathrm{NF}-\kappa \mathrm{B}$ activation in keratinocytes and upregulation of a subset of psoriasis-associated genes, in particular chemokine (C-C motif) ligand 20 (CCL2O), and $I L 8$ genes. Then, the group of Jordan continued to expand the number of cohorts (56), further screening more than 6,000 psoriasis patients and 4,000 controls in multiple regions. Those studies identified 15 novel rare missense mutations, among which the c.425A $>\mathrm{G}$ (p.Glu142Gly) and c.424G $>\mathrm{A}$ (p.Glu142Lys) mutations resulting in, respectively, 4- and 5-fold activation of NF- $\kappa \mathrm{B}$, as compared with wild-type allele. On the other hand, c.511C $>$ A (p.His171Asn) and c.536G $>A$ (p.Arg179His) variants significantly activated the $\mathrm{NF}-\kappa \mathrm{B}$ pathway after the stimulation of tumor necrosis factor- $\alpha$ (TNF- $\alpha$ ). The expression of 13 inflammatory genes (e.g., CCL20, IL8, IL6, colony stimulating factor 2, CSF 2) was also described to be upregulated in keratinocytes of patients with CARD14 gene variants (56).

The aforementioned studies have shown that the gain-of-function mutations of CARD14 gene are associated with psoriasis, but the relationship between $C A R D 14$ gene and GPP remains to be adequately elucidated. In 2014, Sugiura et al (24) found that 4 out of 19 cases of GPP with PV carried the c.526G $>\mathrm{C}$ (p.Arg179His) heterozygous missense mutations in CARD14 gene in a Japanese cohort, and the frequency of allelic mutations was significantly higher than that of controls (3/100) and of patients with PV (4/100). Thus, Sugiura et al suggested that c.526G $>$ C mutation is an important risk factor for GPP with PV, and is distinct from the PV form. However, no pathogenic variants in the CARD14 gene were identified in 11 patients affected by GPP without PV, which supports that GPP alone is a heterogeneous disease and genetically different from GPP with PV. Subsequently, Qin et al (57) identified two novel heterozygous mutations, the c.355A $>$ G (p.Met119Val) and c.497G >A (p.Arg166His), in 62 Chinese patients suffering from GPP with PV, with the frequency of allelic mutations being significantly higher than that of control $(0 / 365)$, but similar to that detected in patients with PV (2/174). In 2015, a significant association between pathogenic c.526G $>$ C mutation and GPP in Asian populations was revealed by the analysis of 105 individuals affected by GPP (58). Subsequently, the group of Mössner (23) and Twelves (22) identified CARD14 variants 

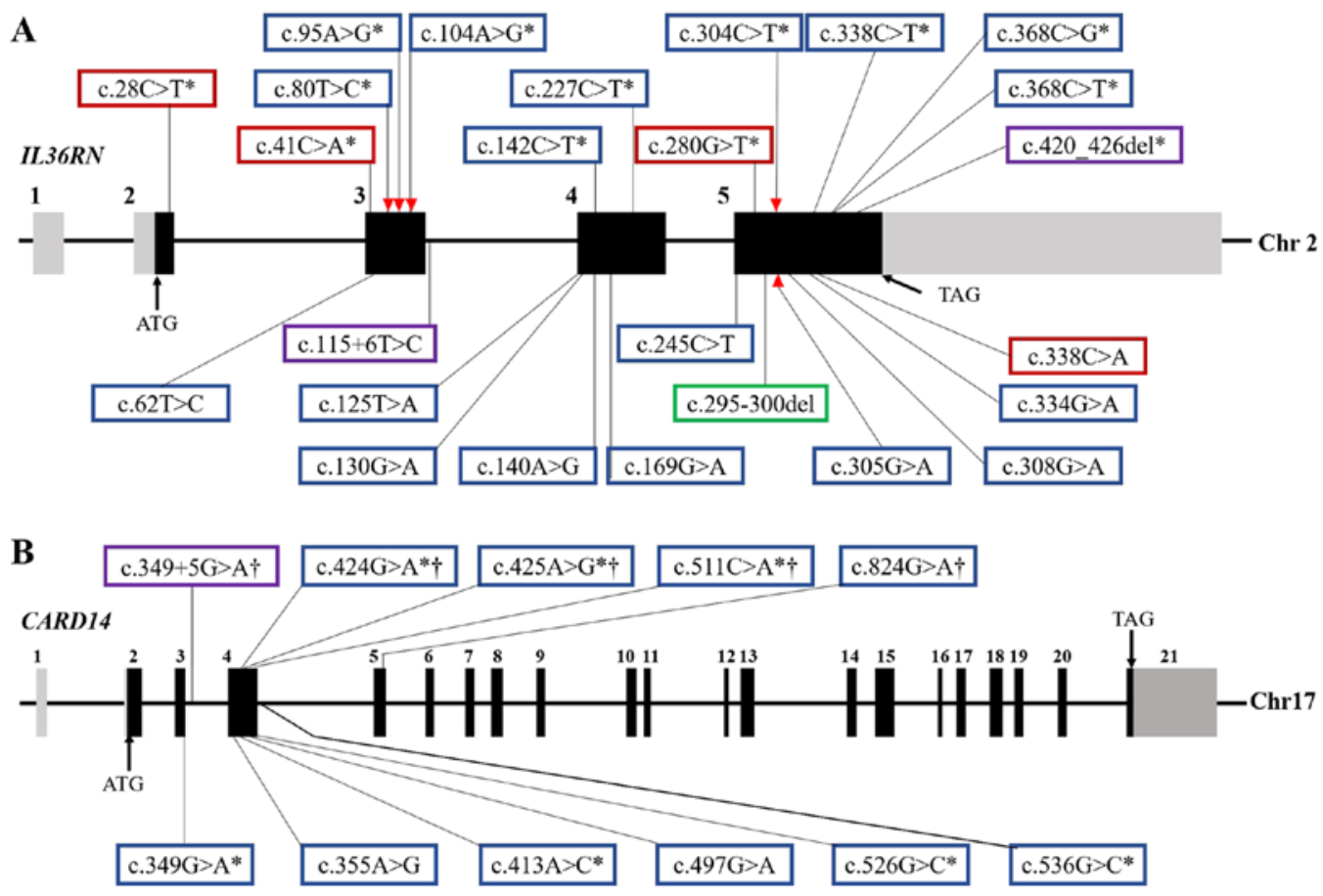

C

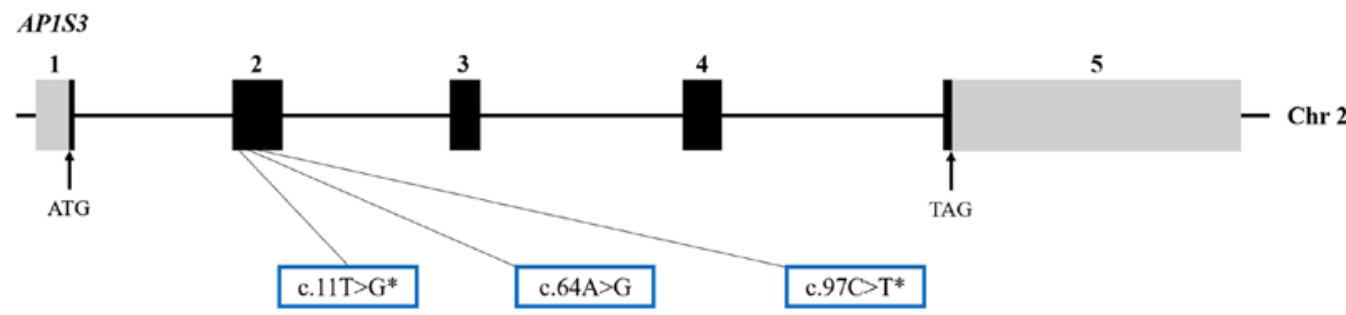

D

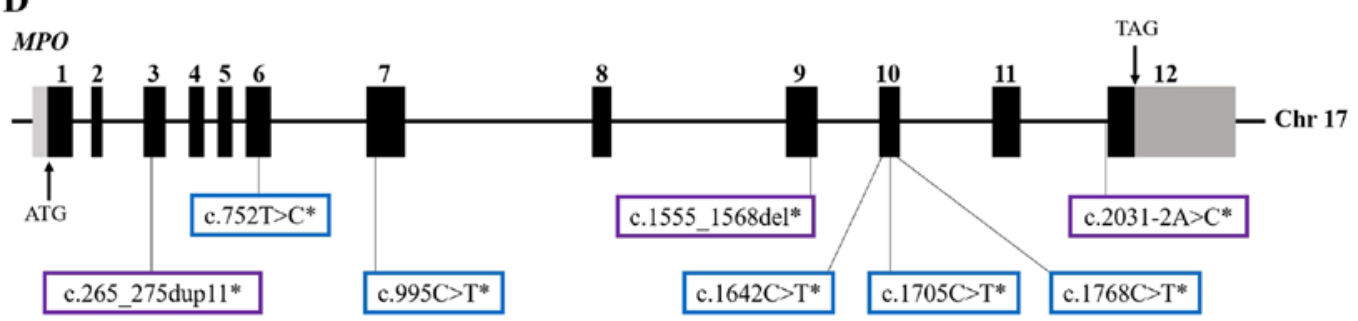

Figure 1. Genomic structure of GPP-related genes and location of the identified variants. Exons and relative non-coding introns of (A) IL36RN, (B) CARD14, (C) APIS3 and (D) MPO genes were shown by solid black and gray boxes, respectively. Blue, red, purple and green boxes represent, respectively, missense, nonsense and frameshift mutations, as well as small fragment deletions. Asterisks indicate the mutations that have been validated by functional assays. The red triangle represents the affected IL-36R binding site after nucleotide substitution, and daggers indicate that the CARD14 mutations only characterized in PV patients.

in patients, even though they were rarely found in patients with GPP. Mössner et al (23) also identified 3 heterozygous missense mutations in CARD14 gene, the c.206G $>\mathrm{A}$ (p.Arg69Gln), c.349G>A, and c.536G >A, in 51 GPP cases, and Twelves et al (22) reported that only 3 out of 251 GPP patients harbored the c. $526 \mathrm{G}>\mathrm{C}$ heterozygous mutation. Taken together, 10 possible pathogenic variants of CARD14 gene have been identified (Fig. 1B, Table III), even though they are not common in GPP patients. Among them, the c.526G $>C$ missense mutation, found in the Asian population, is the most common. Mutations in CARD14 gene are mainly presented in GPP patients concomitantly affected by PV and rarely showing GPP alone (20,26). CARD14 gene mutations specific for PV and GPP patients have not been characterized yet. Therefore, the correlation between $C A R D 14$ gene mutations and the onset of GPP remains to be further elucidated.

Disease-causing gene AP1S3. AP1S3 gene, encoding the core subunit $\sigma 1 \mathrm{C}$ of adaptor protein complex 1 (AP-1), is responsible for the stabilization of AP-1 heterotetramers involved in vesicular trafficking between the trans-Golgi network and endosomes. Findings have shown that loss-of-function mutations of AP1S3 gene are relevant in GPP. In 2014, Setta-Kaffetzi et al (20) identified heterozygosity for the c.11T $>$ G (p.Phe4Cys) and c.97C $>$ T (p.Arg33Trp) missense mutations in APIS3 gene in 15 European patients with various forms of pustular psoriasis (i.e., PPP, ACH, and GPP) and not harboring IL36RN and CARDI4 gene mutations (Fig. 1C). 
Table III. Mutations of CARD14 gene and related characteristics in GPP patients.

\begin{tabular}{|c|c|c|c|c|c|c|}
\hline $\begin{array}{l}\text { Nucleotide } \\
\text { variations }\end{array}$ & $\begin{array}{l}\text { Amino acid } \\
\text { variations }\end{array}$ & $\begin{array}{l}\text { Variants } \\
\text { type }\end{array}$ & $\begin{array}{l}\text { Status of the } \\
\text { mutations }\end{array}$ & Origin & $\begin{array}{c}\text { Effect on } \\
\text { NF- } \kappa \mathrm{B} \text { activation } \\
\text { (vs. wild-type) }\end{array}$ & (Refs.) \\
\hline c. $349 \mathrm{G}>\mathrm{A}$ & p.Gly117Ser & Missense & Het & $\begin{array}{l}\text { European/ } \\
\text { German }\end{array}$ & 3.71 & $(19,23,56)$ \\
\hline c. $355 \mathrm{~A}>\mathrm{G}$ & p.Met119Val & Missense & Het & Chinese & Not reported & $(57)$ \\
\hline c. $413 \mathrm{~A}>\mathrm{C}$ & p.Glu138Ala & Missense & Het & Haitian & 8.95 & $(19,56)$ \\
\hline c. $497 \mathrm{G}>\mathrm{A}$ & p.Arg166His & Missense & Het & Chinese & Not reported & (57) \\
\hline c. $526 \mathrm{G}>\mathrm{C}$ & p.Asp176His & Missense & Het & $\begin{array}{l}\text { Japanese/ } \\
\text { Chinese }\end{array}$ & 2.78 & $\begin{array}{c}(22,24,25, \\
56,58)\end{array}$ \\
\hline c. $536 \mathrm{G}>\mathrm{A}$ & p.Arg179His & Missense & Het & German & $\begin{array}{l}1.38 \text { ( } 2.19 \text { with } \\
\text { TNF- } \alpha \text { stimulation })\end{array}$ & $(23,56)$ \\
\hline c. $424 \mathrm{G}>\mathrm{A} \dagger$ & p.Glu142Lys & Missense & Het & Not reported & 4.03 & $(56)$ \\
\hline c. $425 \mathrm{~A}>\mathrm{G} \dagger$ & p.Glu142Gly & Missense & Het & Not reported & 5 & $(56)$ \\
\hline c. $.511 \mathrm{C}>\mathrm{A} \dagger$ & p.His171Asn & Missense & Het & Not reported & $\begin{array}{l}0.68 \text { ( } 5.95 \text { with } \\
\text { TNF- } \alpha \text { stimulation })\end{array}$ & $(56)$ \\
\hline c. $824 \mathrm{G}>\mathrm{A} \dagger$ & p.Arg275His & Missense & Het & Not reported & Not reported & $(56)$ \\
\hline c. $349+5 \mathrm{G}>\mathrm{A} \dagger$ & Alter splice of intron & Frameshift & Het & Taiwanese & Not reported & (19) \\
\hline
\end{tabular}

†Only characterized in PV patients; Hom, homozygous; Het, heterozygous.

In parallel, these pathogenic variants were not detected in 70 cases from Africa and Asia. In vitro functional assays demonstrated that the substitution of $c .11 \mathrm{~T}>\mathrm{G}$ causes a significant reduction in protein expression, and silencing of AP1S3 in human keratinocytes and HEK293 cells abolishes endosomal translocation of toll-like receptor-3 (TLR3) and TLR3-dependent expression of interferon-\$1 (IFNB1) following induction with polyinosinic-polycytidylic acid [poly(I:C)], an agonist of TLR3 involved in responses to viral infections. Thus, Setta-Kaffetzi et al (20) proposed that defects in vesicular trafficking may be an important pathological basis for auto-inflammatory in pustular psoriasis. In 2016, Mahil et al (26) further demonstrated that knockout of APIS3 gene disrupts autophagy in keratinocytes, thereby resulting in abnormal accumulation of p62, which mediates NF- $\kappa \mathrm{B}$ activation and upregulation of IL-1, IL-36 $\alpha$ and other cytokines. Subsequently, the c.11T $>\mathrm{G}$ and c.97C $>\mathrm{T}$ heterozygous mutations in AP1S3 gene were detected in two European patients with GPP, and the novel c.64A $>\mathrm{G}$ (p.Thr22Ala) homozygous variant was identified in a daughter of a consanguineous marriage (23). All these subjects carried additional homozygous or compound-heterozygous IL36RN mutations, as shown in the study of Mössner et al (23). Similarly, Twelves et al (22) found that 8 out of 251 GPP cases carry c.11T $>\mathrm{G}$ (4 cases) or c.97C $>\mathrm{T}$ (4 cases) heterozygous mutations in the AP1S3 gene, with two carriers of c.11T $>\mathrm{G}$ mutation in $A P 1 S 3$ gene also harboring the known pathogenic IL36RN variants. Of note, $A P 1 S 3$ pathogenic variants are mainly found in Europeans and rarely in East Asians, and variant frequency of $A P 1 S 3$ in GPP patients of European descent is $10.8 \%$ (4/37).

Disease-causing gene MPO. MPO gene encodes myeloperoxidase, a lysosomal hemoprotein located in the azurophilic granules of neutrophils. The correlation between MPO deficiency and the onset of GPP has been characterized only recently $(21,59)$. Although previously described in a single case with pustular psoriasis $(60,61)$, MPO deficiency was not recognized as a genetic risk factor of GPP until 2020 (4), when genetic variants in $M P O$ gene were screened in GPP and in conditions phenotypically related to GPP, such as acral pustular psoriasis (APP) and acute generalized exanthematous pustulosis (AGEP). Vergnano et al (21) first identified the c.2031-2A >C homozygous mutation due to A-C transition in the $3^{\prime}$ end of intron 11 in $M P O$ gene in patients with GPP or APP, and resulting in activation of a cryptic $3^{\prime}$ splice site located 109 bp upstream of canonical 3' splice site, thereby causing a 119-bp fragment insertion and a shift of the reading frame leading to premature protein truncation. In addition, the c.2031-2A >C and c.1705C $>\mathrm{T}$ (p. Arg569Trp) compound heterozygous mutations and c.1555_1568del homozygous variant have been found in patients with AGEP. Of note, all three variants have been repeatedly observed in individuals affected by myeloperoxidase deficiency (MPOD) in which MPO gene variants cause impairment of MPO protein function (62-64). Phenome-wide association studies (pheWAS), which provide a way to identify important relationships between genetic variants and a wide array of phenotypes, and in vitro functional analysis demonstrated that mutations in $M P O$ gene cause an increase of neutrophil accumulation and activity, as well as a reduction in the number of apoptotic neutrophils induced by phorbol myristate acetate (PMA), thus suggesting a role of MPO mutations in GPP pathogenesis. Haskamp et al (59) further confirmed the important role of $M P O$ gene defects in the pathogenesis of GPP. In fact, they showed that 15 out of 74 patients with GPP carried 8 variants in $M P O$ gene, including the following: The c.265_275dup11 
(p.Ser94Alafs*24), c.2031-2A>C, c.1768C >T (p.Arg590Cys) homozygous variants, the c.995C $>\mathrm{T}$ (p.Ala332Val) and c.2031-2A>C (p.Phe678*) compound heterozygous variants and the c.752T $>\mathrm{C}$ (p. Met251Thr), c.995C $>\mathrm{T}$ (p.Ala332Val), c. 2031-2A >C, c.1705C >T, c.1642C >T (p.Arg548Trp), and c.1555_1568del (p.Met519Profs*21) heterozygous variants (Fig. 1D). All these variants were validated as loss-of-function mutations, and, among them, 5 missense mutations (c.1768C $>\mathrm{T}$, c. $1705 \mathrm{C}>\mathrm{T}$, c. $1642 \mathrm{C}>\mathrm{T}$, c. $995 \mathrm{C}>\mathrm{T}$ and c.752T $>\mathrm{C}$ ) reduced MPO activity in HEK cells at different extent (Fig. 1D). While the c.265_275dup11 homozygous mutation determined a lack of MPO expression in neutrophils, the c.2031-2A>C substitution in a splicing site as well as the c.1555_1568del deletion resulted in a premature termination codon and truncated MPO protein. Functional experiments further demonstrated that all four affected individuals showed MPO activity inversely correlating with the activity of NE, CTSG and PR3, three serine proteases that cleave IL-36 precursors into pro-inflammatory forms. These data strongly suggest that MPO deficiency may be involved in the pathogenesis of GPP through regulating the activity of neutrophil and monocytic proteases, and in turn activating pro-inflammatory IL-36 signals. In addition, MPO deficiency caused the reduction of neutrophil extracellular traps (NET) formation in PMA-induced pathway and impaired phagocytosis of neutrophils by monocytes, thereby tolerating the persistence of unfavorable neutrophils and blocking resolution of skin inflammation. Notably, dosage of mutant alleles of $M P O$ gene in individuals affected by GPP also correlated with the age of onset, which is similar to the genotype-phenotype correlation of IL36RN gene and further validates the genetic correlation of GPP. Thus, the novel findings that $M P O$ gene is a pathogenic gene for GPP provide new insights for the elucidation of GPP pathogenesis, even if the in-depth pathogenic mechanism and new pathogenic variants of $M P O$ gene remain to be identified.

\section{IL-1/IL-36-chemokine-neutrophil axis is a potent driver of disease pathology in GPP}

Among the mutations identified in the disease-causing genes IL36RN, CARD14, APIS3 and the newly identified MPO in GPP patients, those present in IL36RN play a pathogenic dominant role. In addition, the IL-1/IL-36-chemokine-neutrophil axis is considered a core pathogenic molecular pathway.

In the present study, we found that all four disease-causing genes share some common pathogenic molecular pathways. IL36RN, CARD14 and APIS3 gene mutations can activate pro-inflammatory signaling pathways via $N F-\kappa B$, and further result in an increased expression of CXCL1-3, IL-1, IL-8, and even IL-36 pro-inflammatory cytokines (18-21). In addition, MPO gene deficiency also promotes the activation of IL-36 signals by regulating the activity of NE, CTSG and PR3 serine proteases (Fig. 2) (59).

Recently, the new disease concept of autoinflammatory keratinization disease (AiKD) has been designated to comprise inflammatory keratinization disorders with genetic autoinflammatory pathomechanisms (65). GPP associated with IL36RN and CARDI4 mutations are included and early-onset GPP is considered a typical one $(66,67)$. Thus, initial genetic causative factors related to the hyperactivation of innate immunity or autoinflammation play dominant roles in the pathogenesis of GPP (65-68). Unanimously, transcriptomic analysis revealed that GPP patients share with patients affected by plaque-type psoriasis the expression of common molecules and pathways related to neutrophil chemotaxis; however, the pathomechanisms operating in GPP patients are more related to innate immunity inflammation $(29,69)$ and those present in plaque psoriasis are more dependent on adaptive immunity responses (29). Thus, it is believed that the IL-1/IL-36 inflammatory axis is central to the disease pathology in GPP, whereas the TNF- $\alpha / \mathrm{IL}-17 / \mathrm{IL}-23$ axis appears to plays a more important role in plaque psoriasis $(31,70,71)$. A gene expression study found that IL-17, TNF- $\alpha$, IL-1, IL-36 and interferons (IFNs) were overexpressed both in GPP and plaque psoriasis lesions, whereas GPP lesions exhibited a higher mRNA level of IL-1 and IL-36 and lower of IL-17 and IFN- $\gamma$, as compared with plaque psoriasis lesions (29). Consequently, a high expression of CXCL1, CXCL2, CXCL8 and IL-8 neutrophil chemoattractants is observed in GPP lesions. Liang et al (69) further demonstrated that GPP, PPP and AGEP pustular skin disorders have a common molecular basis responsible for neutrophil chemotaxis. Of note, overexpression of two inflammatory-related proteins, namely six-transmembrane epithelial antigens of prostate1 and 4 (STEAP1 and STEAP4), was revealed in the three pustular skin disorders. Those molecules promoted neutrophil-rich, pro-inflammatory responses in the skin by favoring induction of IL-1/IL-36 cytokines and CXCL1 and IL-8 neutrophil chemokines in the skin microenvironment. By contrast, STEAP1 and STEAP4 are not upregulated in plaque psoriasis, consistent with a weak induction of neutrophil-activating cytokines in PV. This confirms that neutrophil recruitment is preferentially active in pustular psoriasis, which is distinct from plaque-type psoriasis mostly characterized by IL-17/IL-23 immunity responses (Boehner et al, Mudigonda et al, Coimbra et al, Grine et al, Fanoni et al) (14,72-75). Thus, IL-1/IL-36 inflammatory axis can be considered a pivotal pathogenic pathway typically activated in GPP. Its targeting by novel biological drugs potentially represent an effective therapeutic strategy for GPP treatment.

\section{Novel biologics treatment for GPP based on pathoimmunology}

At present, no standard guidelines for the treatment of GPP have been established, and no specific therapeutic agents for GPP have been approved in the United States or Europe. GPP management currently refers to guidelines for psoriasis vulgaris. However, new biologics targeting cytokines, including TNF- $\alpha /$ IL-17/IL-23 and IL-1/IL-36 axis inhibitors, that are related to pathological immunology bring bright prospects for the treatment of GPP. The most relevant biological treatments have been summarized in Table IV. While TNF- $\alpha /$ IL-17/IL-23 axis is preferentially blocked in plaque psoriasis, IL-1/IL-36-chemokine-neutrophil axis appears to be a more promising therapeutic target in GPP.

IL-1 targeting with biologics has been previously performed in GPP patients using the IL-1 $\alpha$ receptor antagonist (IL-1-RA) anakinra and the IL-1 $\beta$ monoclonal antibodies gevokizumab and canakinumab. Hüffmeier et al (76) reported successful treatment with anakinra, produced by genetic recombination technology, 
Table IV. Summary of biologics treatment for GPP.

\begin{tabular}{|c|c|c|c|c|c|}
\hline Type & Drug & Properties & $\begin{array}{l}\text { Therapeutic } \\
\text { target }\end{array}$ & $\begin{array}{l}\text { IL36RN mutations } \\
\text { of patients enrolled }\end{array}$ & (Refs.) \\
\hline \multirow[t]{3}{*}{ TNF- $\alpha$ inhibitors } & Etanercept & $\begin{array}{l}\text { Recombinant DNA-derived } \\
\text { TNF receptor-IgG fusion protein }\end{array}$ & TNF- $\alpha$ & c.80T>C & $(80-84)$ \\
\hline & Infliximab & Chimeric monoclonal antibody & TNF- $\alpha$ & c. $115+6 \mathrm{~T}>\mathrm{C}$ & $\begin{array}{c}(51,82,83, \\
85,86)\end{array}$ \\
\hline & Adalimumab & Fully human monoclonal antibody & TNF- $\alpha$ & N/A & $\begin{array}{c}(82,83,87, \\
88)\end{array}$ \\
\hline \multirow[t]{3}{*}{ IL-17 inhibitors } & Ixekizumab & Monoclonal antibody & IL-17A & N/A & $(89-91)$ \\
\hline & Secukinumab & Monoclonal antibody & IL-17A & c. $115+6 \mathrm{~T}>\mathrm{C}$ & $(90,92-94)$ \\
\hline & Brodalumab & Monoclonal antibody & IL-17R & N/A & (95) \\
\hline IL-23 inhibitors & Ustekinumab & Monoclonal antibody & IL-12/23 p 40 & c. $227 \mathrm{C}>\mathrm{T}$ & $(96,97)$ \\
\hline IL-1R antagonist & Anakinra & Human recombinant IL-1RA protein & $\mathrm{IL}-1 \mathrm{R}$ & c. $142 \mathrm{C}>\mathrm{T}, \mathrm{C} .338 \mathrm{C}>\mathrm{T}$ & $(76,98)$ \\
\hline \multirow[t]{2}{*}{ IL-1 $\beta$ antagonists } & Gevokizumab & Monoclonal antibody & $\mathrm{IL}-1 \beta$ & N/A & (77) \\
\hline & Canakinumab & Monoclonal antibody & $\mathrm{IL}-1 \beta$ & N/A & (78) \\
\hline IL-36R antagonist & BI655130 & Monoclonal antibody & IL-36R & c. $80 \mathrm{~T}>\mathrm{C}, \mathrm{c} .115+6 \mathrm{~T}>\mathrm{C}$ & (79) \\
\hline
\end{tabular}

N/A, not applicable.
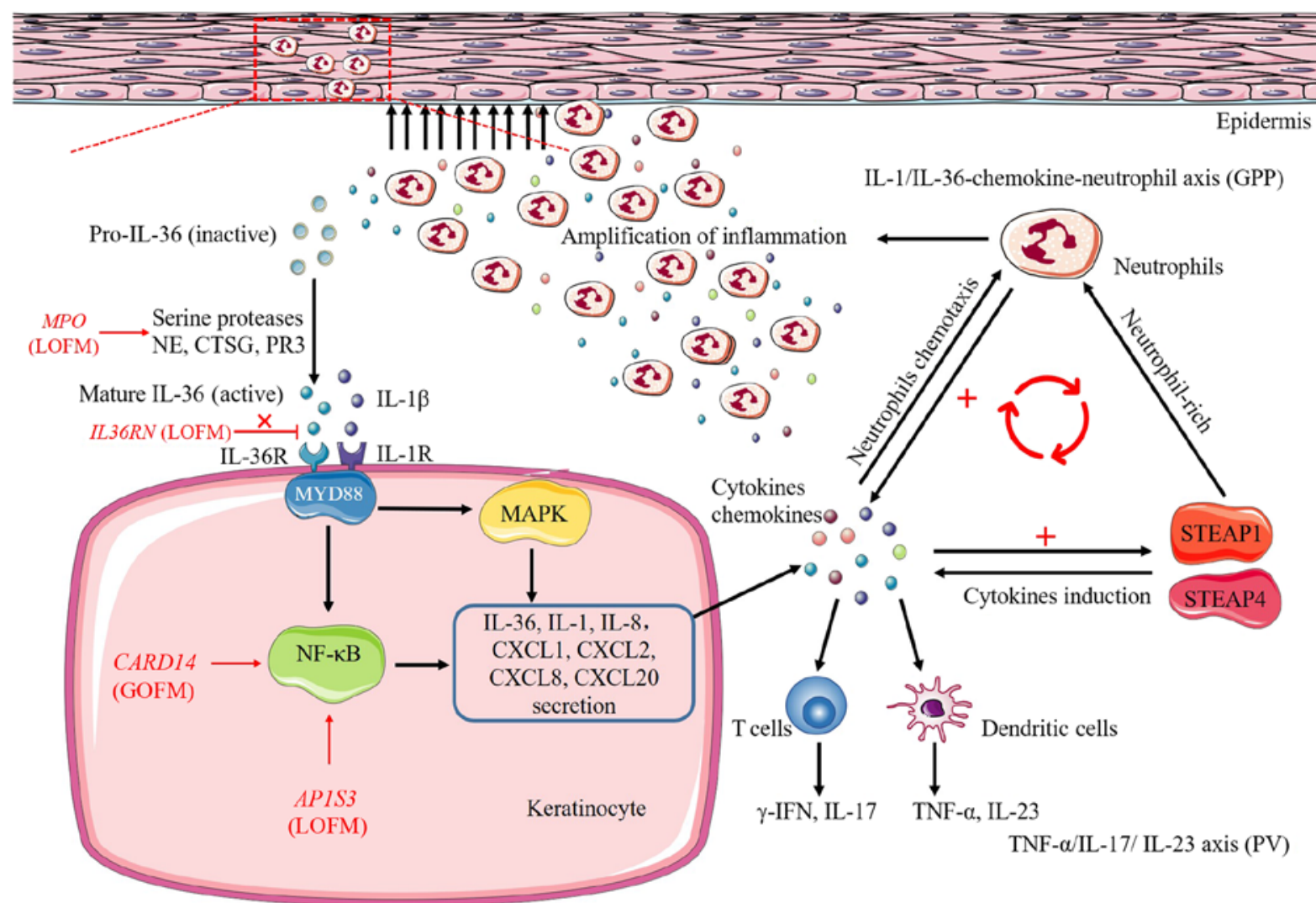

Figure 2. Pathways and processes of inflammatory responses induced by $I L 36 R N, C A R D 14, A P 1 S 3$ and $M P O$ genes. Loss-of-function mutations in both $I L 36 R N$ and $M P O$ genes cause upregulation of IL-36 signaling, the former result in the inability of IL-36Ra to antagonize and limit the pro-inflammatory effects of IL-36, the latter upregulate the activity of NE, CTSG and PR3, three serine proteases that cleave IL-36 precursors into pro-inflammatory forms. Upregulated IL-36 signaling further activates the downstream pro-inflammatory NF- $\mathrm{\kappa B}$ and MAPK pathways by binding to IL-36 receptor, further leading to secretion of chemokines/cytokines, IL-36, IL-1, IL-8, CXCL1, CXCL2, CXCL8, CXCL20, from the keratinocyte and resulting in the activation of neutrophils, $\mathrm{T}$ cells and dendritic cells. Secretion of cytokines also promotes neutrophil-rich, cytokines induction, thereby amplifying the pro-inflammatory responses in the skin by two inflammatory-related proteins STEAP1 and STEAP4, ultimately forming a vicious cycle of enhancing inflammation. In addition, CARD14 gain-of-function mutations and APIS3 loss-of-function mutations hyperactivate NF- $\mathrm{kB}$ pathway and are involved in the processes of inflammatory responses. Red or black arrows, secretion or activation; $\perp$, inhibition; MyD88, myeloid differentiation primary response 88; NF- $\kappa \mathrm{B}$, nuclear factor- $\kappa \mathrm{B}$; MAPK, mitogen-activated protein kinase; LOFM, loss-of-function mutations; GOFM, gain-of-function mutations; STEAP1, six-transmembrane epithelial antigens of prostate 1; STEAP4, six-transmembrane epithelial antigens of prostate 4. 
in a patient with GPP carrying the mutation of IL36RN gene. Gevokizumab is an effective monoclonal antibody blocking the pro-inflammatory cytokine IL-1 $\beta$ and its signal transduction in inflammatory cells. Mansouri et al (77) reported the 79 and $65 \%$ reduction in Psoriasis Activity and Severity Index (PASI) score at weeks 4 and 12 after treatment with gevokizumab in two patients with severe, recalcitrant GPP. Skendros et al (78) reported a case of abrupt and severe form of GPP with hypereosinophilia and cholestatic hepatitis, completely cleared after treatment with canakinumab, leading to anakinra discontinuation for persistent hypersensitivity skin reactions. The new monoclonal antibody BI655130 targeting IL-36 receptor can effectively block the IL-36 signaling pathway and alleviate inflammatory response in GPP patients. A study on the treatment of GPP with BI655130 showed that all 7 GPP patients carrying homozygous IL36RN mutation $(\mathrm{n}=3)$, or heterozygous mutation in CARDI4 $(\mathrm{n}=1)$ or wild-type alleles $(n=4)$ significantly responded to BI655130 after 4-week therapy (79). The finding suggested that IL-36R inhibition with a single dose of BI655130 can effectively alleviate the severity of GPP regardless of the presence of the disease-causing gene mutation and has great potential for future clinical treatment of GPP. No serious adverse reactions and recurrences related to therapy were reported in the abovementioned studies. However, since clinical studies are very limited and current data mainly derive from case reports or small single-arm studies, further clinical investigations on larger populations are required in order to determine the clinical efficacy, duration of effect, and adverse events associated with the drug.

\section{Conclusion and perspectives}

The advances in our understanding of the genetic variation underlying GPP has provided an outstanding framework for basic research on the pathogenesis and treatment of GPP. These advances have suggested several new theories while simultaneously generating significant challenges. Evidence on the correlation between genotype and clinical phenotype of GPP characterized by various studies suggested that GPP is a heterogeneous disease with distinct clinical manifestations and genetic characteristics, and requires a separate diagnosis and treatment. Previous studies reported that some GPP patients carry two or three disease-causing gene variants or multiple mutations in one disease-causing gene $(17,22,23,59)$, and some healthy subjects who carry the homozygous mutation of c.115+6T $>\mathrm{C}$ in IL36RN gene, which theoretically leads to the complete loss of IL36RN function, did not develop GPP until adulthood (15). Thus, it is suggested that the genetic basis for the onset of GPP is an oligogenic rather than a purely monogenic inheritance. The pathogenic variants in all four genes found in patients with GPP can work together and promote skin inflammation by increasing the production of pro-inflammatory cytokines in keratinocytes, which ultimately shift the balance towards substantial inflammation. Studies also found that large number of GPP patients did not carry any known genetic variations in IL36RN, CARDI4, APIS3 and $M P O$ genes (23), which suggests that some novel variants located in introns or regulatory regions and other genetic factors outside these four genes are expected to contribute to the pathogenesis of the GPP. Therefore, further screening and validating more pathogenic variants or novel pathogenic genes may provide key insights into disease pathogenesis, as well as the corresponding treatment and prevention strategies of GPP. We found that the function of numerous possible pathogenic variants reported remains to be validated. Therefore, functional research models in vitro and in vivo are required to be established for further elucidating the pathological mechanism. Although great progress in therapy of GPP with biologics has been made, current treatment studies are limited owing to a lack of data from controls and the number of patient cohorts due to GPP rarity. Thus, it is necessary to expand the patient cohorts from different countries and ethnicities to provide more reliable data on long-term maintenance of safety, efficacy and the impact of withdrawal/re-treatment with new biologics.

\section{Acknowledgements}

The authors would like to express their gratitude to EditSprings (https://www.editsprings.com/) for the expert linguistic services provided.

\section{Funding}

This review is supported by the Sichuan Science and Technology Program (grant nos. 2019YFS0332, 2019YFS0038, and 2020YFQ0045).

\section{Availability of data and materials}

Not applicable

\section{Authors' contributions}

JZ and JL conceived and designed the review. JZ and QL conducted formal literature search and analysis. QL, YC and $\mathrm{XW}$ contributed to the raw data reviewing. JZ was involved in the original draft preparation, JL was involved in the writing and review of the manuscript. All the authors have read and approved the final manuscript.

\section{Ethics approval and consent to participate}

Not applicable.

\section{Patient consent for publication}

Not applicable.

\section{Competing interests}

The authors declare that they have no competing interests.

\section{References}

1. Navarini AA, Burden AD, Capon F, Mrowietz U, Puig L, Köks S, Kingo K, Smith C, Barker JN; ERASPEN Network: European consensus statement on phenotypes of pustular psoriasis. J Eur Acad Dermatol Venereol 31: 1792-1799, 2017.

2. Baker H and Ryan TJ: Generalized pustular psoriasis. A clinical and epidemiological study of 104 cases. Br J Dermatol 80: 771-793, 1968.

3. Ohkawara A, Yasuda H, Kobayashi H, Inaba Y, Ogawa H, Hashimoto I and Imamura S: Generalized pustular psoriasis in Japan: Two distinct groups formed by differences in symptoms and genetic background. Acta Derm Venereol 76: 68-71, 1996. 
4. Augey F, Renaudier P and Nicolas JF: Generalized pustular psoriasis (Zumbusch): A French epidemiological survey. Eur J Dermatol 16: 669-673, 2006.

5. Ito T, Takahashi H, Kawada A, Iizuka $H$ and Nakagawa $H$; Japanese Society For Psoriasis Research: Epidemiological survey from 2009 to 2012 of psoriatic patients in Japanese society for psoriasis research. J Dermatol 45: 293-301, 2018.

6. Takahashi H, Nakamura K, Kaneko F, Nakagawa $H$ and Iizuka H; JAPANESE SOCIETY FOR PSORIASIS RESEARCH: Analysis of psoriasis patients registered with the Japanese society for psoriasis research from 2002-2008. J Dermatol 38: 1125-1129, 2011.

7. Chen L, Huang X, Xiao Y, Su J, Shen M and Chen X: Prevalence and risk factors of atopic dermatitis, psoriasis, acne, and urticaria in China. Zhong Nan Da Xue Xue Bao Yi Xue Ban 45: 449-455, 2020 (In English, Chinese).

8. Talaee R, Hajheydari Z, Moghaddam AY, Moraveji SA and Ravandi BF: Prevalence of oral mucosal lesions and their association with severity of psoriasis among psoriatic patients referred to dermatology clinic: A cross-sectional study in Kashan/Iran. Open Access Maced J Med Sci 5: 978-982, 2017.

9. Griffiths CE and Barker JN: Pathogenesis and clinical features of psoriasis. Lancet 370: 263-271, 2007.

10. Steffen C: William John Munro and Munro's abscess, and Franz Kogoj and Kogoj's spongiform pustule. Am J Dermatopathol 24: 364-368, 2002

11. Crowley JJ, Pariser DM and Yamauchi PS: A brief guide to pustular psoriasis for primary care providers. Postgrad Med: $1-15,2020$ (Online Ahead of Print).

12. Benjegerdes KE, Hyde K, Kivelevitch D and Mansouri B Pustular psoriasis: Pathophysiology and current treatment perspectives. Psoriasis (Auckl) 6: 131-144, 2016.

13. Sugiura K, Takemoto A, Yamaguchi M, Takahashi H, Shoda Y, Mitsuma T, Tsuda K, Nishida E, Togawa Y, Nakajima K, et al: The majority of generalized pustular psoriasis without psoriasis vulgaris is caused by deficiency of interleukin-36 receptor antagonist. J Invest Dermatol 133: 2514-2521, 2013.

14. Boehner A, Navarini AA and Eyerich K: Generalized pustular psoriasis-a model disease for specific targeted immunotherapy, systematic review. Exp Dermatol 27: 1067-1077, 2018.

15. Li M, Han J, Lu Z, Li H, Zhu K, Cheng R, Jiao Q, Zhang C, Zhu C, Zhuang Y, et al: Prevalent and rare mutations in IL-36RN gene in Chinese patients with generalized pustular psoriasis and psoriasis vulgaris. J Invest Dermatol 133: 2637-2639, 2013.

16. Li X, Chen M, Fu X, Zhang Q, Wang Z, Yu G, Yu Y, Qin P, $\mathrm{Wu}$ W, Pan F, et al: Mutation analysis of the IL36RN gene in Chinese patients with generalized pustular psoriasis with/without psoriasis vulgaris. J Dermatol Sci 76: 132-138, 2014.

17. Hussain S, Berki DM, Choon SE, Burden AD, Allen MH, Arostegui JI, Chaves A, Duckworth M, Irvine AD, Mockenhaupt M, et al: IL36RN mutations define a severe autoinflammatory phenotype of generalized pustular psoriasis J Allergy Clin Immunol 135: 1067-1070.e9, 2015.

18. Marrakchi S, Guigue P, Renshaw BR, Puel A, Pei XY Fraitag S, Zribi J, Bal E, Cluzeau C, Chrabieh M, et al: Interleukin-36-receptor antagonist deficiency and generalized pustular psoriasis. N Engl J Med 365: 620-628, 2011.

19. Jordan CT, Cao L, Roberson ED, Pierson KC, Yang CF, Joyce CE, Ryan C, Duan S, Helms CA, Liu Y, et al: PSORS2 is due to mutations in CARD14. Am J Hum Genet 90: 784-795, 2012.

20. Setta-Kaffetzi N, Simpson MA, Navarini AA, Patel VM, Lu HC, Allen MH, Duckworth M, Bachelez H, Burden AD, Choon SE, et al: AP1S3 mutations are associated with pustular psoriasis and impaired Toll-like receptor 3 trafficking. Am J Hum Genet 94: 790-797, 2014

21. Vergnano M, Mockenhaupt M, Benzian-Olsson N, Paulmann M, Grys K, Mahil SK, Chaloner C, Barbosa IA, August S, Burden $\mathrm{AD}$, et al: Loss-of-function myeloperoxidase mutations are associated with increased neutrophil counts and pustular skin disease. Am J Hum Genet 107: 539-543, 2020.

22. Twelves S, Mostafa A, Dand N, Burri E, Farkas K, Wilson R, Cooper HL, Irvine AD, Oon HH, Kingo K, et al: Clinical and genetic differences between pustular psoriasis subtypes. J Allergy Clin Immunol 143: 1021-1026, 2019.

23. Mössner R, Wilsmann-Theis D, Oji V, Gkogkolou P, Löhr S, Schulz P, Körber A, Prinz JC, Renner R, Schäkel K, et al: The genetic basis for most patients with pustular skin disease remains elusive. Br J Dermatol 178: 740-748, 2018.

24. Sugiura K, Muto M and Akiyama M: CARD14 c.526G $>C$ (p.Asp176His) is a significant risk factor for generalized pustular psoriasis with psoriasis vulgaris in the Japanese cohort. J Invest Dermatol 134: 1755-1757, 2014.
25. Li L, You J, Fu X, Wang Z, Sun Y, Liu H and Zhang F: Variants of CARD14 are predisposing factors for generalized pustular psoriasis (GPP) with psoriasis vulgaris but not for GPP alone in a Chinese population. Br J Dermatol 180: 425-426, 2019.

26. Mahil SK, Twelves S, Farkas K, Setta-Kaffetzi N, Burden AD, Gach JE, Irvine AD, Képíró L, Mockenhaupt M, Oon HH, et al: AP1S3 mutations cause skin autoinflammation by disrupting keratinocyte autophagy and up-regulating IL-36 production. J Invest Dermatol 136: 2251-2259, 2016.

27. Towne JE, Garka KE, Renshaw BR, Virca GD and Sims JE: Interleukin (IL)-1F6, IL-1F8, and IL-1F9 signal through IL-1Rrp2 and IL-1RAcP to activate the pathway leading to NF-kappaB and MAPKs. J Biol Chem 279: 13677-13688, 2004.

28. Buhl AL and Wenzel J: Interleukin-36 in infectious and inflammatory skin diseases. Front Immunol 10: 1162, 2019.

29. Johnston A, Xing X, Wolterink L, Barnes DH, Yin Z, Reingold L Kahlenberg JM, Harms PW and Gudjonsson JE: IL-1 and IL-36 are dominant cytokines in generalized pustular psoriasis. J Allergy Clin Immunol 140: 109-120, 2017

30. Onoufriadis A, Simpson MA, Pink AE, Di Meglio P, Smith CH, Pullabhatla V, Knight J, Spain SL, Nestle FO, Burden AD, et al: Mutations in IL36RN/IL1F5 are associated with the severe episodic inflammatory skin disease known as generalized pustular psoriasis. Am J Hum Genet 89: 432-437, 2011.

31. Furue K, Yamamura K, Tsuji G, Mitoma C, Uchi H, Nakahara T, Kido-Nakahara M, Kadono T and Furue M: Highlighting interleukin-36 signalling in plaque psoriasis and pustular psoriasis. Acta Derm Venereol 98: 5-13, 2018.

32. Cowen EW and Goldbach-Mansky R: DIRA, DITRA, and new insights into pathways of skin inflammation: What's in a name? Arch Dermatol 148: 381-384, 2012

33. Aksentijevich I, Masters SL, Ferguson PJ, Dancey P, Frenkel J, van Royen-Kerkhoff $\mathrm{A}$, Laxer R, Tedgård $\mathrm{U}$, Cowen $\mathrm{EW}$, Pham TH, et al: An autoinflammatory disease with deficiency of the interleukin-1-receptor antagonist. N Engl J Med 360: 2426-2437, 2009.

34. Reddy S, Jia S, Geoffrey R, Lorier R, Suchi M, Broeckel U, Hessner MJ and Verbsky J: An autoinflammatory disease due to homozygous deletion of the IL1RN locus. N Engl J Med 360: 2438-2444, 2009.

35. Sugiura K, Takeichi T, Kono M, Ogawa Y, Shimoyama Y, Muro Y and Akiyama M: A novel IL36RN/IL1F5 homozygous nonsense mutation, p.Arg10X, in a Japanese patient with adult-onset generalized pustular psoriasis. Br J Dermatol 167: 699-701, 2012

36. Kanazawa N, Nakamura T, Mikita N and Furukawa F: Novel IL36RN mutation in a Japanese case of early onset generalized pustular psoriasis. J Dermatol 40: 749-751, 2013.

37. Farooq M, Nakai H, Fujimoto A, Fujikawa H, Matsuyama A, Kariya N, Aizawa A, Fujiwara H, Ito M and Shimomura Y: Mutation analysis of the IL36RN gene in 14 Japanese patients with generalized pustular psoriasis. Hum Mutat 34: 176-183, 2013.

38. Tauber M, Bal E, Pei XY, Madrange M, Khelil A, Sahel H, Zenati A, Makrelouf M, Boubridaa K, Chiali A, et al: IL36RN mutations affect protein expression and function: A basis for genotype-phenotype correlation in pustular diseases. J Invest Dermatol 136: 1811-1819, 2016.

39. Setta-Kaffetzi N, Navarini AA, Patel VM, Pullabhatla V, Pink AE, Choon SE, Allen MA, Burden AD, Griffiths CE, Seyger MM, et al: Rare pathogenic variants in IL36RN underlie a spectrum of psoriasis-associated pustular phenotypes. J Invest Dermatol 133: 1366-1369, 2013.

40. Sugiura K, Nakasuka A, Kono H, Kono M and Akiyama M: Impetigo herpetiformis with IL36RN mutations in a Chinese patient: A founder haplotype of c.115+6T $>C$ in East Asia. J Dermatol Sci 79: 319-320, 2015.

41. Shiratori T, Fukai K, Yasumizu M, Taguchi R, Tsuruta D, Abe Y, Hozumi Y and Suzuki T: IL36RN gene analysis of two Japanese patients with generalized pustular psoriasis. Int J Dermatol 54: e60-e62, 2015 .

42. Wang Y, Cheng R, Lu Z, Guo Y, Yan M, Liang J, Huang P, Li M and Yao Z: Clinical profiles of pediatric patients with GPP alone and with different IL36RN genotypes. J Dermatol Sci 85: 235-240, 2017.

43. Renert-Yuval Y, Horev L, Babay S, Tams S, Ramot Y, Zlotogorski A and Molho-Pessach V: IL36RN mutation causing generalized pustular psoriasis in a Palestinian patient. Int $\mathbf{J}$ Dermatol 53: 866-868, 2014.

44. Ueda Y, Komine M, Kamiya K, Tsuda H, Maekawa T, Murata S and Ohtsuki M: Generalized pustular psoriasis in a 92-year-old man with a homozygous nonsense mutation in IL36RN. J Dermatol 45: 326-328, 2018. 
45. Ellingford JM, Black GC, Clayton TH, Judge M, Griffiths CE and Warren RB: A novel mutation in IL36RN underpins childhood pustular dermatosis. J Eur Acad Dermatol Venereol 30: 302-305, 2016

46. Rossi-Semerano L, Piram M, Chiaverini C, De Ricaud D Smahi A and Koné-Paut I: First clinical description of an infant with interleukin-36-receptor antagonist deficiency successfully treated with anakinra. Pediatrics 132: e1043-e1047, 2013.

47. Körber A, Mössner R, Renner R, Sticht H, Wilsmann-Theis D, Schulz P, Sticherling M, Traupe H and Hüffmeier U: Mutations in IL36RN in patients with generalized pustular psoriasis. J Invest Dermatol 133: 2634-2637, 2013

48. Takeichi T, Togawa Y, Okuno Y, Taniguchi R, Kono M, Matsue H, Sugiura K and Akiyama M: A newly revealed IL36RN mutation in sibling cases complements our IL36RN mutation statistics for generalized pustular psoriasis. J Dermatol Sci 85: 58-60, 2017.

49. Wang TS, Chiu HY, Hong JB, Chan CC, Lin SJ and Tsai TF: Correlation of IL36RN mutation with different clinical features of pustular psoriasis in Chinese patients. Arch Dermatol Res 308: 55-63, 2016

50. Abbas O, Itani S, Ghosn S, Kibbi AG, Fidawi G, Farooq M Shimomura Y and Kurban M: Acrodermatitis continua of Hallopeau is a clinical phenotype of DITRA: Evidence that it is a variant of pustular psoriasis. Dermatology 226: 28-31, 2013.

51. Sugiura K, Endo K, Akasaka T and Akiyama M: Successful treatment with infliximab of sibling cases with generalized pustular psoriasis caused by deficiency of interleukin-36 receptor antagonist. J Eur Acad Dermatol Venereol 29: 2054-2056, 2015.

52. Song HS, Yun SJ, Park S and Lee ES: Gene mutation analysis in a Korean patient with early-onset and recalcitrant generalized pustular psoriasis. Ann Dermatol 26: 424-425, 2014.

53. Liang J, Zhang H, Guo Y, Yang K, Ni C, Yu H, Kong X, Li M, $\mathrm{Lu} \mathrm{Z}$ and Yao Z: Coinheritance of generalized pustular psoriasis and familial Behcet-like autoinflammatory syndrome with variants in IL36RN and TNFAIP3 in the heterozygous state. J Dermatol 46: 907-910, 2019.

54. Scudiero I, Zotti T, Ferravante A, Vessichelli M, Vito P and Stilo R: Alternative splicing of CARMA2/CARD14 transcripts generates protein variants with differential effect on NF- $\mathrm{B}$ activation and endoplasmic reticulum stress-induced cell death. J Cell Physiol 226: 3121-3131, 2011.

55. Bertin J, Wang L, Guo Y, Jacobson MD, Poyet JL, Srinivasula SM, Merriam S, DiStefano PS and Alnemri ES: CARD11 and CARD14 are novel caspase recruitment domain (CARD)/membrane-associated guanylate kinase (MAGUK) family members that interact with BCL10 and activate NF-kappa B. J Biol Chem 276: 11877-11882, 2001.

56. Jordan CT, Cao L, Roberson ED, Duan S, Helms CA, Nair RP, Duffin KC, Stuart PE, Goldgar D, Hayashi G, et al: Rare and common variants in CARD14, encoding an epidermal regulator of NF-kappaB, in psoriasis. Am J Hum Genet 90: 796-808, 2012

57. Qin P, Zhang Q, Chen M, Fu X, Wang C, Wang Z, Yu G, Yu Y, Li X, Sun Y, et al: Variant analysis of CARD14 in a Chinese Han population with psoriasis vulgaris and generalized pustular psoriasis. J Invest Dermatol 134: 2994-2996, 2014

58. Berki DM, Liu L, Choon SE, David Burden A, Griffiths CEM, Navarini AA, Tan ES, Irvine AD, Ranki A, Ogo T, et al: Activating CARD14 mutations are associated with generalized pustular psoriasis but rarely account for familial recurrence in psoriasis vulgaris. J Invest Dermatol 135: 2964-2970, 2015.

59. Haskamp S, Bruns H, Hahn M, Hoffmann M, Gregor A, Löhr S, Hahn J, Schauer C, Ringer M, Flamann C, et al: Myeloperoxidase modulates inflammation in generalized pustular psoriasis and additional rare pustular skin diseases. Am J Hum Genet 107: $527-538,2020$

60. De Argila D, Dominguez JD, Lopez-Estebaranz JL and Iglesias L: Pustular psoriasis in a patient with myeloperoxidase deficiency. Dermatology 193: 270, 1996

61. Stendahl O, Coble BI, Dahlgren C, Hed J and Molin L: Myeloperoxidase modulates the phagocytic activity of polymorphonuclear neutrophil leukocytes. Studies with cells from a myeloperoxidase-deficient patient. J Clin Invest 73: 366-373, 1984.

62. Kizaki M, Miller CW, Selsted ME and Koeffler HP: Myeloperoxidase (MPO) gene mutation in hereditary MPO deficiency. Blood 83: 1935-1940, 1994.

63. Marchetti C, Patriarca P, Solero GP, Baralle FE and Romano M: Genetic studies on myeloperoxidase deficiency in Italy. Jpn J Infect Dis 57: S10-S12, 2004.

64. Marchetti C, Patriarca P, Solero GP, Baralle FE and Romano M Genetic characterization of myeloperoxidase deficiency in Italy. Hum Mutat 23: 496-505, 2004.
65. Akiyama M, Takeichi T, McGrath JA and Sugiura K: Autoinflammatory keratinization diseases. J Allergy Clin Immunol 140: 1545-1547, 2017.

66. Akiyama M: Early-onset generalized pustular psoriasis is representative of autoinflammatory keratinization diseases. J Allergy Clin Immunol 143: 809-810, 2019.

67. Kanazawa N: Designation of autoinflammatory skin manifestations with specific genetic backgrounds. Front Immunol 11: 475, 2020

68. Takeichi T and Akiyama M: Familial or sporadic porokeratosis as an autoinflammatory keratinization disease. J Dermatol 46 : e125-e126, 2019.

69. Liang Y, Xing X, Beamer MA, Swindell WR, Sarkar MK, Roberts LW, Voorhees JJ, Kahlenberg JM, Harms PW, Johnston A and Gudjonsson JE: Six-transmembrane epithelial antigens of the prostate comprise a novel inflammatory nexus in patients with pustular skin disorders. J Allergy Clin Immunol 139: 1217-1227, 2017.

70. Ogawa E, Sato Y, Minagawa A and Okuyama R: Pathogenesis of psoriasis and development of treatment. J Dermatol 45: 264-272, 2018.

71. Nestle FO, Conrad C, Tun-Kyi A, Homey B, Gombert M, Boyman O, Burg G, Liu YJ and Gilliet M: Plasmacytoid predendritic cells initiate psoriasis through interferon-alpha production. J Exp Med 202: 135-143, 2005.

72. Mudigonda P, Mudigonda T, Feneran AN, Alamdari HS, Sandoval L and Feldman SR: Interleukin-23 and interleukin-17: Importance in pathogenesis and therapy of psoriasis. Dermatol Online J 18: 1, 2012.

73. Coimbra S, Oliveira H, Reis F, Belo L, Rocha S, Quintanilha A, Figueiredo A, Teixeira F, Castro E, Rocha-Pereira P and Santos-Silva A: Interleukin (IL)-22, IL-17, IL-23, IL-8, vascular endothelial growth factor and tumour necrosis factor- $\alpha$ levels in patients with psoriasis before, during and after psoralen-ultraviolet A and narrowband ultraviolet B therapy. Br J Dermatol 163: 1282-1290, 2010.

74. Grine L, Dejager L, Libert C and Vandenbroucke RE: An inflammatory triangle in psoriasis: TNF, type I IFNs and IL-17. Cytokine Growth Factor Rev 26: 25-33, 2015.

75. Fanoni D, Venegoni L, Vergani B, Tavecchio S, Cattaneo A, Leone BE, Berti E and Marzano AV: Evidence for a role of autoinflammation in early-phase psoriasis. Clin Exp Immunol 198: 283-291, 2019.

76. Hüffmeier U, Wätzold M, Mohr J, Schön MP and Mössner R: Successful therapy with anakinra in a patient with generalized pustular psoriasis carrying IL36RN mutations. Br J Dermatol 170: 202-204, 2014

77. Mansouri B, Richards L and Menter A: Treatment of two patients with generalized pustular psoriasis with the interleukin-1 $\beta$ inhibitor gevokizumab. Br J Dermatol 173: 239-241, 2015.

78. Skendros P, Papagoras C, Lefaki I, Giatromanolaki A, Kotsianidis I, Speletas M, Bocly V, Theodorou I, Dalla V and Ritis K: Successful response in a case of severe pustular psoriasis after interleukin-1 $\beta$ inhibition. Br J Dermatol 176: 212-215, 2017.

79. Bachelez H, Choon SE, Marrakchi S, Burden AD, Tsai TF, Morita A, Turki H, Hall DB, Shear M, Baum P, et al: Inhibition of the interleukin-36 pathway for the treatment of generalized pustular psoriasis. N Engl J Med 380: 981-983, 2019.

80. Fialová J, Vojáčková N, Vaňousová D and Hercogová J: Juvenile generalized pustular psoriasis treated with etanercept. Dermatol Ther 27: 105-108, 2014

81. Esposito M, Mazzotta A, Casciello C and Chimenti S: Etanercept at different dosages in the treatment of generalized pustular psoriasis: A case series. Dermatology 216: 355-360, 2008.

82. Viguier M,Aubin F,DelaporteE,Pagès C,PaulC,Beylot-Barry M, Goujon C, Rybojad M and Bachelez H; Groupe de Recherche sur le Psoriasis de la Société Française de Dermatologie: Efficacy and safety of tumor necrosis factor inhibitors in acute generalized pustular psoriasis. Arch Dermatol 148: 1423-1425, 2012.

83. Saikaly SK and Mattes M: Biologics and pediatric generalized pustular psoriasis: An emerging therapeutic trend. Cureus 8: e652, 2016

84. Cuperus E, Koevoets R, van der Smagt JJ, Toonstra J, de Graaf M, Frenkel $\mathrm{J}$ and Pasmans SGMA: Juvenile interleukin-36 receptor antagonist deficiency (DITRA) with c.80T $>$ C (p.Leu27Pro) mutation successfully treated with etanercept and acitretin. JAAD Case Rep 4: 192-195, 2018.

85. Adachi A, Komine M, Hirano T, Tsuda H, Karakawa M, Murata S and Ohtsuki M: Case of generalized pustular psoriasis exacerbated during pregnancy, successfully treated with infliximab. J Dermatol 43: 1439-1440, 2016. 
86. Pan J, Qiu L, Xiao T and Chen HD: Juvenile generalized pustular psoriasis with IL36RN mutation treated with short-term infliximab. Dermatol Ther 29: 164-167, 2016.

87. Morita A, Yamazaki F, Matsuyama T, Takahashi K, Arai S, Asahina A, Imafuku S, Nakagawa H, Hasegawa Y, Williams D, et al: Adalimumab treatment in Japanese patients with generalized pustular psoriasis: Results of an open-label phase 3 study. J Dermatol 45: 1371-1380, 2018.

88. Matsumoto A, Komine M, Karakawa M, Kishimoto $\mathbf{M}$ and Ohtsuki M: Adalimumab administration after infliximab therapy is a successful treatment strategy for generalized pustular psoriasis. J Dermatol 44: 202-204, 2017.

89. Egawa G, Honda T and Kabashima K: Long-term efficacy of ixekizumab in erythrodermic and generalized pustular psoriasis patients. J Eur Acad Dermatol Venereol 33: 259, 2019.

90. Wilsmann-Theis D, Schnell LM, Ralser-Isselstein V, Bieber T, Schön MP, Hüffmeier U and Mössner R: Successful treatment with interleukin-17A antagonists of generalized pustular psoriasis in patients without IL36RN mutations. J Dermatol 45: 850-854, 2018.

91. Okubo Y, Mabuchi T, Iwatsuki K, Elmaraghy H, Torisu-Itakura H, Morisaki Y and Nakajo K: Long-term efficacy and safety of ixekizumab in Japanese patients with erythrodermic or generalized pustular psoriasis: Subgroup analyses of an open-label, phase 3 study (UNCOVER-J). J Eur Acad Dermatol Venereol 33: 325-332, 2019.

92. Ho PH and Tsai TF: Successful treatment of refractory juvenile generalized pustular psoriasis with secukinumab monotherapy: A case report and review of published work. J Dermatol 45: 1353-1356, 2018

93. Imafuku S, Honma M, Okubo Y,Komine M, Ohtsuki M, Morita A, Seko N, Kawashima N, Ito S, Shima T and Nakagawa H: Efficacy and safety of secukinumab in patients with generalized pustular psoriasis: A 52-week analysis from phase III open-label multicenter Japanese study. J Dermatol 43: 1011-1017, 2016.
94. Gabeff R, Safar R, Leducq S, Maruani A, Sarrabay G, Touitou I and Samimi M: Successful therapy with secukinumab in a patient with generalized pustular psoriasis carrying homozygous IL36RN p.His32Arg mutation. Int J Dermatol 58: e16-e17, 2019.

95. Yamasaki K, Nakagawa H, Kubo Y and Ootaki K; Japanese Brodalumab Study Group: Efficacy and safety of brodalumab in patients with generalized pustular psoriasis and psoriatic erythroderma: Results from a 52-week, open-label study. Br J Dermatol 176: 741-751, 2017.

96. Storan ER, O'Gorman SM and Markham T: Generalized pustular psoriasis treated with ustekinumab. Clin Exp Dermatol 41: 689-690, 2016.

97. Arakawa A, Ruzicka T and Prinz JC: Therapeutic efficacy of interleukin 12/interleukin 23 blockade in generalized pustular psoriasis regardless of IL36RN mutation status. JAMA Dermatol 152: 825-828, 2016.

98. Viguier M, Guigue P, Pages C, Smahi A and Bachelez H: Successful treatment of generalized pustular psoriasis with the interleukin-1-receptor antagonist Anakinra: Lack of correlation with IL1RN mutations. Ann Intern Med 153: 66-67, 2010.

(i) (-) This work is licensed under a Creative Commons Attribution-NonCommercial-NoDerivatives 4.0 International (CC BY-NC-ND 4.0) License. 